\title{
Mineralogical and geochemical characteristics of the Cu-Ag mineralization from the Kyaukse Sabe Taung deposit, western margin of the Shan Plateau, Myanmar
}

\author{
Aung Myo THU ${ }^{1,2, *}$, Adam PIESTRZYŃSKI ${ }^{1}$ and Krzysztof FOLTYN ${ }^{1}$ \\ 1 AGH University of Science and Technology, Faculty of Geology, Geophysics and Environmental Protection, \\ al. A. Mickiewicza 30, 30-059 Kraków, Poland \\ 2 Mandalay University, Department of Geology, 73rd Street, Maha Aungmye Township, Mandalay, Myanmar
}

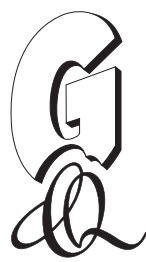

Thu, A.M., Piestrzyński, A., Foltyn, K., 2020. Mineralogical and geochemical characteristics of the Cu-Ag mineralization from the Kyaukse Sabe Taung deposit, western margin of the Shan Plateau, Myanmar. Geological Quarterly, 64 (1): 16-28, doi: 10.7306/gq.1514

Associate Editor: Jacek Szczepański

The Kyaukse Sabe Taung copper deposit is located in the western margin of the Shan Plateau, central Myanmar. It has estimated reserves of $1.6 \mathrm{Mt}$ of ore grading $3.15 \% \mathrm{Cu}$, with additional $\mathrm{Ag}$ and $\mathrm{Au}$ enrichment. This deposit is typically hosted by Middle Ordovician limestone of the Wunbye Formation and the mineralization is controlled by the regional structures. The ore-mineral assemblage consists of pyrite, chalcopyrite, tetrahedrite, chalcocite, covellite, bornite, native copper, malachite, azurite, cuprite, tenorite, silver amalgams and Bi-sulphosalts, members of hammarite-aikinite series. Gangue minerals are quartz, dolomite, ankerite and calcite. Silver mineralization is represented by acanthite and by silver amalgams with a high content of $\mathrm{Hg}$, ranging from 2.15 to $26.68 \mathrm{wt}$ \%. Silver minerals are a result of supergene alteration of $\mathrm{Ag}$ - and $\mathrm{Hg}$-bearing tetrahedrite and could increase economic value of the deposit. Silver association is located within the lowermost part of the supergene zone in the deposit, and tracking the redox barrier position can help to identify parts of the orebody with silver enrichment. The $\delta^{34} S$ values of chalcopyrite are +5.7 to $+10.7 \%$ and those of tetrahedrite are +1.6 to $+1.7 \%$.

Key words: Kyaukse Sabe Taung Cu deposit, Silver amalgams, Bi-sulphosalts.

\section{INTRODUCTION}

Myanmar has more than 70 copper occurrences, including world-class high-sulphidation $\mathrm{Cu} \pm \mathrm{Au}$ deposits at Monywa (Khin Zaw et al., 2017). The Kyaukse Sabe Taung copper deposit (not to be confused with the more famous Sabe Taung $\mathrm{Cu}$ deposit near Monywa) is located at the western margin of the Shan Plateau, east of the Central Lowland of Myanmar (Fig. 1). Mining was initiated in this area by the Myanmar kings prior to 1900 and produced $150 \mathrm{~kg}$ of silver (Khin Zaw et al., 2017; Mitchell, 2018). During World War I, adits were made and unsuccessful attempts to develop the deposit were undertaken in the late 1930s (Mitchell, 2018). Currently (2018) in this area, one Chinese company operates small-scale underground mining focused solely on extracting copper ores. The Kyaukse Sabe Taung deposit has estimated reserves of $1.6 \mathrm{Mt}$ of ore grading $3.15 \% \mathrm{Cu}$, and trench sampling results showed up to

\footnotetext{
* Corresponding author, e-mail: aungmyothu@agh.edu.pl Received: Frebruary 22, 2019; accepted: November 26, 2019; first published online: February 27, 2020
}

$72.86 \mathrm{~g} / \mathrm{t} \mathrm{Ag}$ and $1.6 \mathrm{~g} / \mathrm{t} \mathrm{Au}$ (DGSE, 2013). The deposit is hosted in Upper Ordovician limestone of the Wunbye Formation and its genetic classification is still debated with proposals ranging from a deformed MVT//rish-type deposit to a structurally controlled orogenic base metal-gold deposit (Khin Zaw et al., 2017). In this study, authors are focusing on polymetallic, economically important mineralization in order to identify carriers of precious metals and provide the first description of mineralogy and chemical composition of copper, silver and bismuth minerals from the Kyaukse Sabe Taung copper deposit.

\section{GEOLOGICAL SETTING}

Tectonic position and location of the study area on a regional geological map are shown in Figures 1 and 2. Myanmar can be subdivided into three provinces: namely, the Western Fold Belt (WFB) in the west, the Central Lowland (CL) in the middle, and the Eastern Highland $(\mathrm{EH})$ or Shan Plateau in the east (Maung Thein, 1973). The Kyaukse Sabe Taung deposit is located in the western margin of the Shan Plateau (Fig. 1A), which includes the eastern Kachin-Shan-Tanintharyi region. It is also known as the Sino-Burma Ranges and represents the largest tectonic unit in Myanmar (Bender, 1983). This deposit 


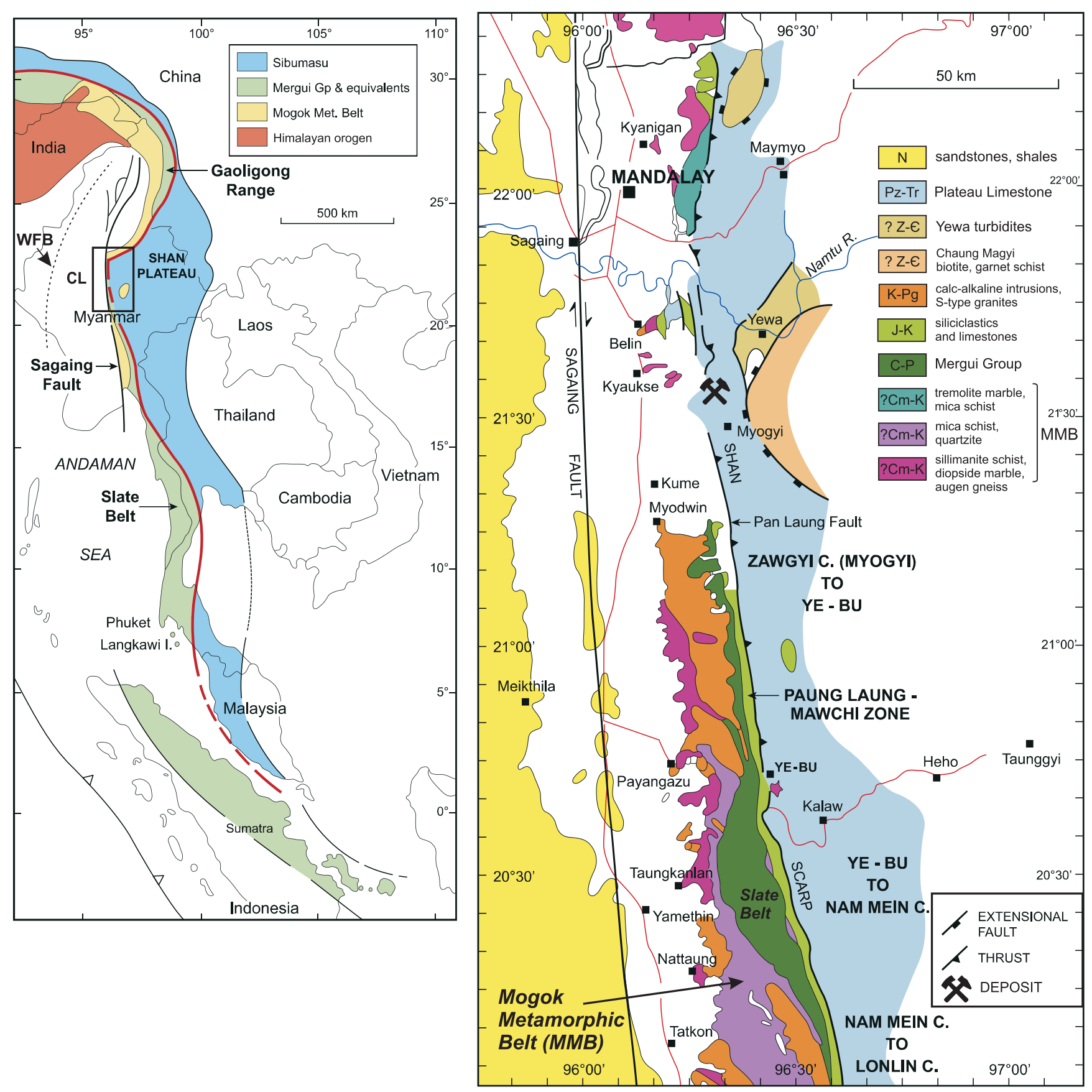

Fig. 1. Location maps of the study area

A - position of the Slate Belt and Shan Plateau in Southeast Asia; WFB - Western Fold Belt, CL - Central Lowland (modified from Mitchell, 2018); B - simplified geological map of the area south of Mandalay with location of the Kyaukse Sabe Taung deposit (modified from Mitchell, 2018)

occupies a small segment in the western fringe of the Shan Plateau. To the east, the Shan Plateau, with an average elevation of $\sim 1000 \mathrm{~m}$ above sea level, is composed mainly of a thick succession of Upper Precambrian, Paleozoic and Mesozoic sedimentary rocks. It is separated from the Central Lowland by the Shan Scarps area (Fig. 1B) developed over the Pan Laung Fault, which is interpreted as a fold-and-thrust belt (Barley et al., 2003, Bertrand and Rangin, 2003). To the west, they are flanked by the Mergui Group or Slate Belt, composed mainly of terrigenous clastic rocks, which in turn are flanked by a belt of metamorphic and foliated intrusive rocks, known as the Mogok Metamorphic Belt (MMB) (Fig. 1B). This belt is $\sim 50 \mathrm{~km}$ wide and composed mostly of mica schists, gneisses, marbles, granulite and quartzite with a metamorphic record ranging from greenschist to granulite facies (Bender, 1983; Mitchell et al., 2007). The MMB is parallel to the Shan Scarp on its entire length, but it bends north-eastwards near Mogok (latitude $\sim 23^{\circ} \mathrm{N}$ ) on its northern termination. The MMB resulted from 


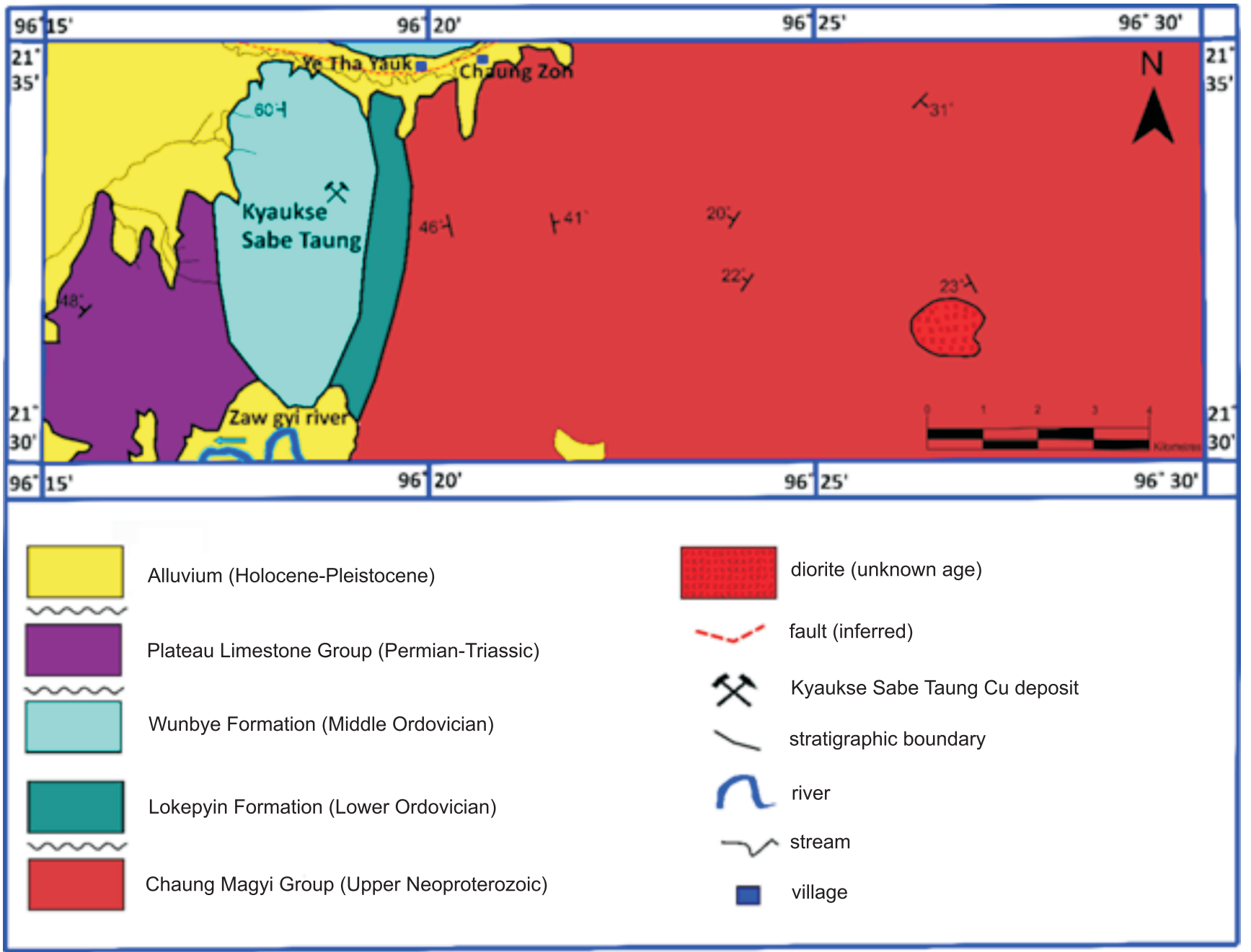

Fig. 2. Simplified geological map of the Kyaukse Sabe Taung copper deposit area (modified after Khin Zaw et al., 2017)

metamorphism caused by emplacement of syn- to late-tectonic intrusive rocks in the Eastern Highland and Central Lowland (Maung Thein, 1973). The Sagaing Fault, a major strike-slip right-lateral continental fault and one of the major tectonic boundaries in Myanmar (Fig. 1), is located further west of the deposit. North-east and south of this deposit, the Paleozoic rocks are underlain by low-grade metasedimentary rocks (Upper Neoproterozoic in age) exposed east of the Kyaukse Sabe Taung area.

\section{GEOLOGY OF THE DEPOSIT AREA}

Detailed field mapping shows that the investigated area comprises Upper Neoproterozoic metasedimentary rocks (Chaung Magyi Group) intruded by diorite, Lower Ordovician limestones (Lokepyin Formation), Middle Ordovician limestones (Wunbye Formation) and Permian-Triassic limestones (Plateau Limestone Group) (Fig. 2; Tin Aung Myint et al., 2014; Khin Zaw et al., 2017).

The unfossiliferous low-grade metasedimentary rocks of the Chaung Magyi Group are considered to be more likely of Upper Neoproterozoic or Cambrian age, based on detrital zir- con ages (Dew et al., 2019). They are composed mainly of slates and phyllites, with minor occurrences of metagreywackes and schists. Diorite (of unknown age) intruded into the phyllite unit located southeast from the study area (Fig. 2). Aung Myo Thu (2014) described the metamorphism of the Chaung Magyi Group in the southern part of this deposit as regional of greenschist facies conditions. These rocks are overlain uncomfortably by a succession of medium- to thick-bedded micaceous siltstones of the Lokepyin Formation, designated by Myint Lwin Thein (1973) as Lower Ordovician based on lithology, stratigraphic correlation and fauna content. The Middle Ordovician Wunbye Formation comprises mainly medium- to thick-bedded limestones, siltstones and dolomites. The limestones are finely crystalline, grey to bluish grey, sometimes oolitic, and with pinkish or yellow silty materials in the forms of burrows, specks, pellets or irregular and regular laminae (Myint Lwin Thein, 1973). The thick sequence of limestones and dolomites covering the lower Paleozoic rocks of the Shan Plateau was first named the Plateau Limestone by La Touche (1913) and this unit is composed mostly of dolomitic limestone (Fig. 2).

Mineralization occurs in a linear north-northeast trending fracture or a vein traceable from gossan outcrops (Mitchell, 2018) and hosted by the Middle Ordovician metamorphosed limestone of the Wunbye Formation. Within this unit, bulk of the 
sulphide minerals is found as disseminations in quartz veins, quartz-calcite veins and in fractures. The main mineralized quartz veins are sub-horizontal and 1-2 m wide. However, some minor vertical and younger veins occasionally cross-cut the horizontal veins. The major quartz vein is generally trending $\mathrm{NE}-\mathrm{SW}$ and gently dipping to the east. It is characterized by the presence of polymetallic mineralization composed of chalcopyrite, tetrahedrite, minor amount of pyrite, chalcocite, covellite, bornite and oxide minerals, such as tenorite, cuprite, azurite and malachite. Host rocks show subhorizontal to nearly vertical bedding. Fractures and foliation planes in the Kyaukse Sabe Taung area developed due to tectonic activity (Kyu Kyu Maw, 2014). Tin Aung Myint et al. (2014) proposed that the mineralization of the Kyaukse Sabe Taung copper deposit was controlled by regional tectonic structures.

\section{ANALYTICAL TECHNIQUES}

This study is based on several samples collected in the underground mine - adit No. 27 of the Kyaukse Sabe Taung copper deposit, Kyaukse District, Mandalay region, Myanmar. Polished thin-sections were investigated in both reflected and transmitted light microscopes. Silver minerals, tetrahedrite and Bi-sulphosalt, minerals important from the economic point of view as a potential by-product, were analysed using both SEM-EDS and EPMA-WDS systems.

\section{SEM-EDS AND EPMA}

A FEI QUANTA 200 Field Emission Gun scanning electron microscope (SEM) equipped with the energy dispersive spectrometer (EDS) was used to document textures and to carry out semi-quantitative analyses in order to identify selected minerals, while the microprobe chemical composition of minerals was performed using a JEOL Super Probe JXA-8230 electron microprobe (EPMA) at the Laboratory of Critical Elements AGH-KGHM, AGH University of Science and Technology, Kraków, Poland. The electron microprobe was operated in the wavelength-dispersion mode at an accelerating voltage of $20 \mathrm{kV}$, a probe current of $20 \mathrm{nA}$, and a focused beam with a diameter of $1 \mu \mathrm{m}$. Counting times of $20 \mathrm{~s}$ on peak and $10 \mathrm{~s}$ on both $(+)$ and $(-)$ backgrounds were used. For acanthite, the analytical conditions were $20 \mathrm{kV}$ accelerating voltage, $10 \mathrm{nA}$ probe current and $5 \mathrm{Fm}$ beam size. Counting times for Ag-amalgams, tetrahedrite and $\mathrm{Bi}$-sulphosalts were $10 \mathrm{~s}$ on peak and $5 \mathrm{~s}$ on both (+) and (-) backgrounds. The following standards and spectral lines were used: GaAs (As $L \alpha)$, Se (Se $\mathrm{L} \alpha)$, ZnS (S K $\alpha), \operatorname{Ag}(\mathrm{Ag} \mathrm{L} \alpha), \mathrm{HgS}(\mathrm{Hg} \mathrm{M} \alpha)$, Bi metallic (Bi M $\alpha)$, $\mathrm{Fe}$ or $\mathrm{FeS}_{2}$, (Fe K $\left.\alpha\right) \mathrm{PbS}(\mathrm{Pb} \mathrm{M} \alpha), \mathrm{Au}(100 \%)(\mathrm{Au} \mathrm{L} \alpha), \mathrm{CuS}_{2}$ $(\mathrm{Cu} \mathrm{K} \alpha)$ and $\mathrm{ZnS}(\mathrm{Zn} \mathrm{K} \alpha)$. Data were corrected to the ZAF procedure using JEOL software for electron microprobe. The detection limits for analysed elements were as follows: in silver minerals $\mathrm{Sb}-0.09 \%, \mathrm{Hg}-0.20 \%, \mathrm{~Pb}-0.16 \%, \mathrm{Ag}-0.37 \%, \mathrm{Cu}$ $-0.05 \%, \mathrm{Fe}-0.03 \%, \mathrm{Au}-0.08 \%, \mathrm{Bi}-0.06 \%$ and $\mathrm{As}-0.14 \%$, for tetrahedrite $\mathrm{S}-0.02 \%, \mathrm{Sb}-0.07 \%, \mathrm{~Pb}-0.11 \%, \mathrm{Hg}-$ $0.06 \%, \mathrm{Ag}-0.02 \%, \mathrm{Bi}-0.05 \%, \mathrm{Te}-0.04 \%, \mathrm{Cu}-0.04 \%, \mathrm{Zn}-$ $0.04 \%, \mathrm{Fe}-0.03 \%$, As $-0.01 \%$, Co $-0.04 \%, \mathrm{Ni}-0.03 \%$ and $\mathrm{Se}-0.10 \%$, for Bi-sulphosalts $\mathrm{Sb}-0.09 \%, \mathrm{~S}-0.02 \%, \mathrm{Bi}-$ $0.16 \%, \mathrm{Ag}-0.05 \%, \mathrm{Cu}-0.05 \%, \mathrm{~Pb}-0.08 \%, \mathrm{Fe}-0.03 \%$, Te$0.03 \%, \mathrm{Au}-0.08 \%$ and $\mathrm{Se}-0.15 \%$, respectively. Acanthite stars were identified during routine semi-quantitative analyses using the energy dispersive spectrometer (EDS) system related to the FEI electron microscope.

\section{STABLE ISOTOPES OF SULPHUR}

A sulphide-bearing vein, containing chalcopyrite and tetrahedrite, was separated from crushed fresh rock vein samples and examined using a binocular microscope. Then, segregated mineral concentrates were pulverized in an agate mortar. Sulphur isotope analyses were undertaken the Laboratory of Petroleum Geochemistry, Faculty of Geology, Geophysics and Environmental Protection, AGH-UST, Kraków. The $\delta^{34} S$ values were calculated using calibration curves obtained using International Atomic Energy Agency's (IAEA) reference materials (IAEA-S-1 and -S-3). The data precision is $\pm 0.2 \%$.

\section{HYDROTHERMAL ALTERATION}

At the Kyaukse Sabe Taung copper deposit, well-developed wall-rock alterations are a result of silicification, kaolinization, chloritization, carbonatization, dolomitization and hematitization processes (Kyu Kyu Maw, 2014; Tin Aung Myint et al., 2014; Khin Zaw et al., 2017). Majority of the copper and silver are found in partly altered and silicified limestones; therefore, the type of alteration was identified by petrographic observation of hand specimens and thin-sections. Silicification, kaolinization and chloritization were observed in limestones of the Wunbye Formation and are closely associated with the ore-bearing quartz-calcite veins (Fig. $3 A-C$ ). Ore minerals are sometimes cut by later quartz veins (Fig. 3D-E), but oxidation processes are most pronounced, resulting in supergene mineralization (Fig. 3E) often accompanied by hematitization (Fig. 3F).

\section{ORE MINERALOGY AND PARAGENETIC SEQUENCES}

The following ore minerals have been identified in the samples: pyrite $\left(\mathrm{FeS}_{2}\right)$, chalcopyrite $\left(\mathrm{CuFeS}_{2}\right)$, bornite $\left(\mathrm{Cu}_{5} \mathrm{FeS}_{4}\right)$, chalcocite $\left(\mathrm{Cu}_{2} \mathrm{~S}\right)$, tetrahedrite $\left(\mathrm{Cu}_{6}\left[\mathrm{Cu}_{4}(\mathrm{Fe}, \mathrm{Zn}, \mathrm{Hg}, \mathrm{Ag})_{2}\right] \mathrm{Sb}_{4} \mathrm{~S}_{13}\right)$, covellite (CuS), tenorite (CuO), Bi-sulphosalts of the hammarite-aikinite series, silver amalgams, native copper, cuprite $\left(\mathrm{Cu}_{2} \mathrm{O}\right)$, malachite $\left[\mathrm{Cu}_{2}\left(\mathrm{CO}_{3}\right)(\mathrm{OH})_{2}\right]$, azurite $\mathrm{Cu}_{3}\left(\mathrm{CO}_{3}\right)_{2}(\mathrm{OH})_{2}$, hematite and goethite. Gangue minerals are quartz, dolomite and calcite. Hypogene ores are composed mainly of chalcopyrite, tetrahedrite and bornite, while chalcocite and covellite are likely supergene in origin, as they occur in association with azurite and malachite.

The earliest sulphide, pyrite, is abundant and occurs as idiomorphic and allotriomorphic crystals, $100-500 \mu \mathrm{m}$ in size and enclosed in chalcopyrite and quartz (Fig. 4A). Tetrahedrite shows euhedral to subhedral grains, often intergrown with chalcopyrite, and usually fills free spaces and fissures in the host rocks (Fig. 4B). Chalcopyrite is the most abundant mineral of hypogene stage, sometimes with a minor amount of bornite and tetrahedrite (Fig. 4C). It usually forms at the rims of quartz-carbonate veins and commonly shows massive aggregate forms (Fig. 4A). Covellite is a common mineral in this deposit; however, it occurs only as small blades and aggregates replacing chalcopyrite (Fig. 4D), mainly in the upper zone of a supergene horizon in association with other copper sulphides, native $\mathrm{Cu}$, carbonates and oxides. Some optical properties (deep blue colour and isotropy in crossed polars) suggested also the presence of digenite, which usually forms rim textures on aggregates of tetrahedrite, and chalcopyrite (Fig. 4D). Bismuthsulphosalt minerals are associated mainly with chalcopyrite, but 

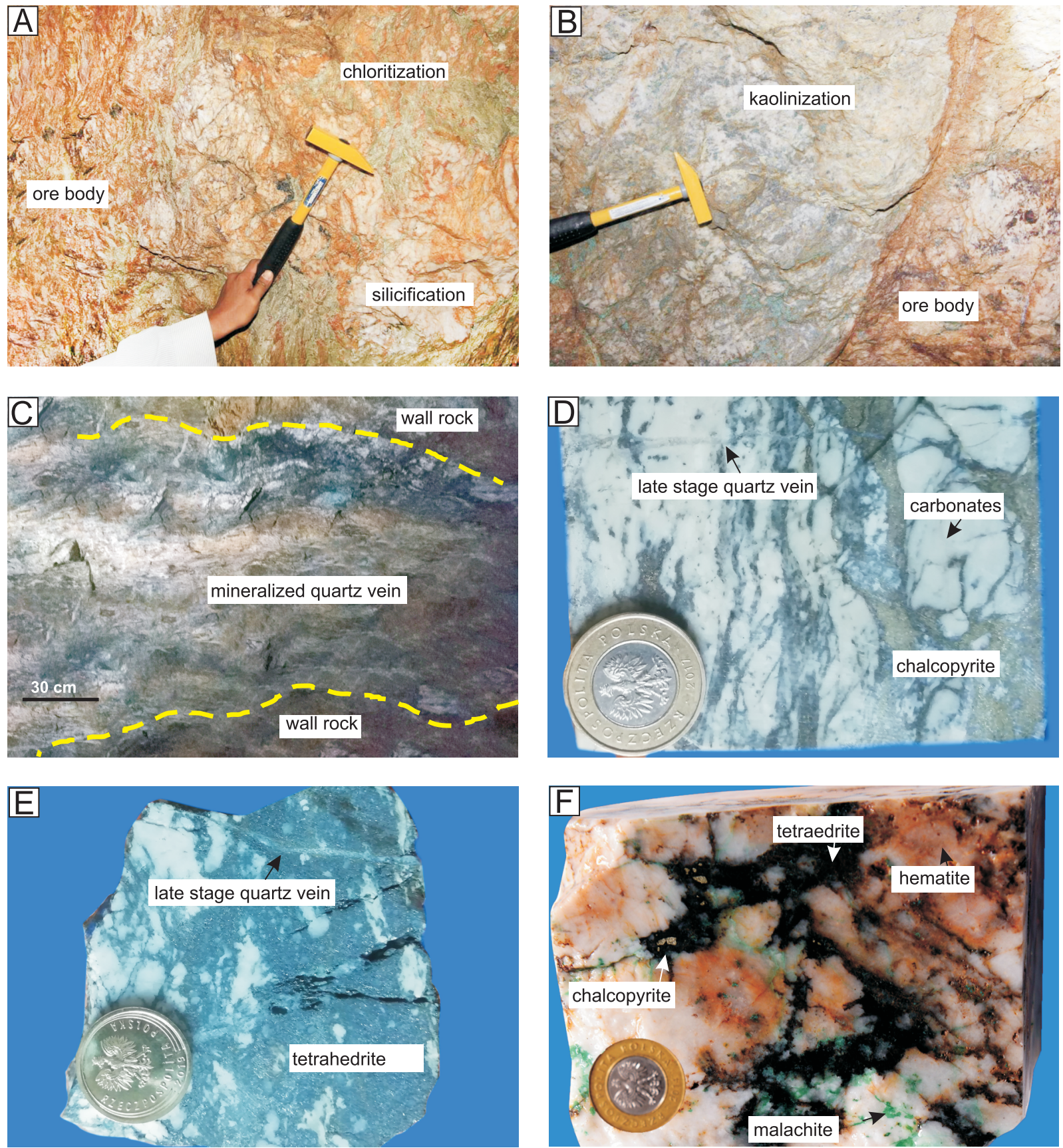

Fig. 3. Photographs showing typical wall-rock alteration and hydrothermal minerals assemblages in the Kyaukse Sabe Taung copper deposit

A - well-developed silicification and chloritization near the oxidized ore body; B - kaolinization developed along the ore body; C mineralized quartz vein injected into the host rock of Middle Ordovician limestone; $\mathbf{D}$ - hand specimen of copper mineralization in a carbonate vein, cross-cut by a late stage quartz vein (coin diameter $=22 \mathrm{~mm}$ ); $\mathbf{E}$ - chalcopyrite disseminated in a tetrahedrite vein (coin diameter $=20 \mathrm{~mm}$ ); $\mathbf{F}$ - hypogene minerals (chalcopyrite and tetrahedrite) with a supergene assemblage (malachite, hematite) (coin diameter $=22 \mathrm{~mm}$ )

occasionally are observed as inclusions and fracture fillings in pyrite. Their position suggests a younger stage of mineralization (Fig. 4E). Relics of native copper are associated with secondary copper minerals, such as cuprite, tenorite and malachite (Fig. 4F).

Chalcocite commonly occurs as fine-grained and xenomorphic aggregates, usually in malachite (Fig. 5A). Fe-oxides and hydroxides (Fig. 5B) are common in the oxidized zones where azurite, malachite and silver amalgams are found (Fig.
5C-F). Supergene minerals of copper and silver are often associated with tetrahedrite crystals. Silver amalgams are intimately related to altered tetrahedrite aggregates, sometimes forming ring-type textures (Fig. 5D). They are mostly irregular, more or less scattered, and individual silver grains are $\sim 100 \mu \mathrm{m}$ in size. The alteration rims developed on tetrahedrite crystals are well-visible in BSE images (Fig. 5E, F).

Acanthite $\left(\mathrm{Ag}_{2} \mathrm{~S}\right)$ was found on the edge of tetrahedrite grains, suggesting it is a late phase formed during the young al- 

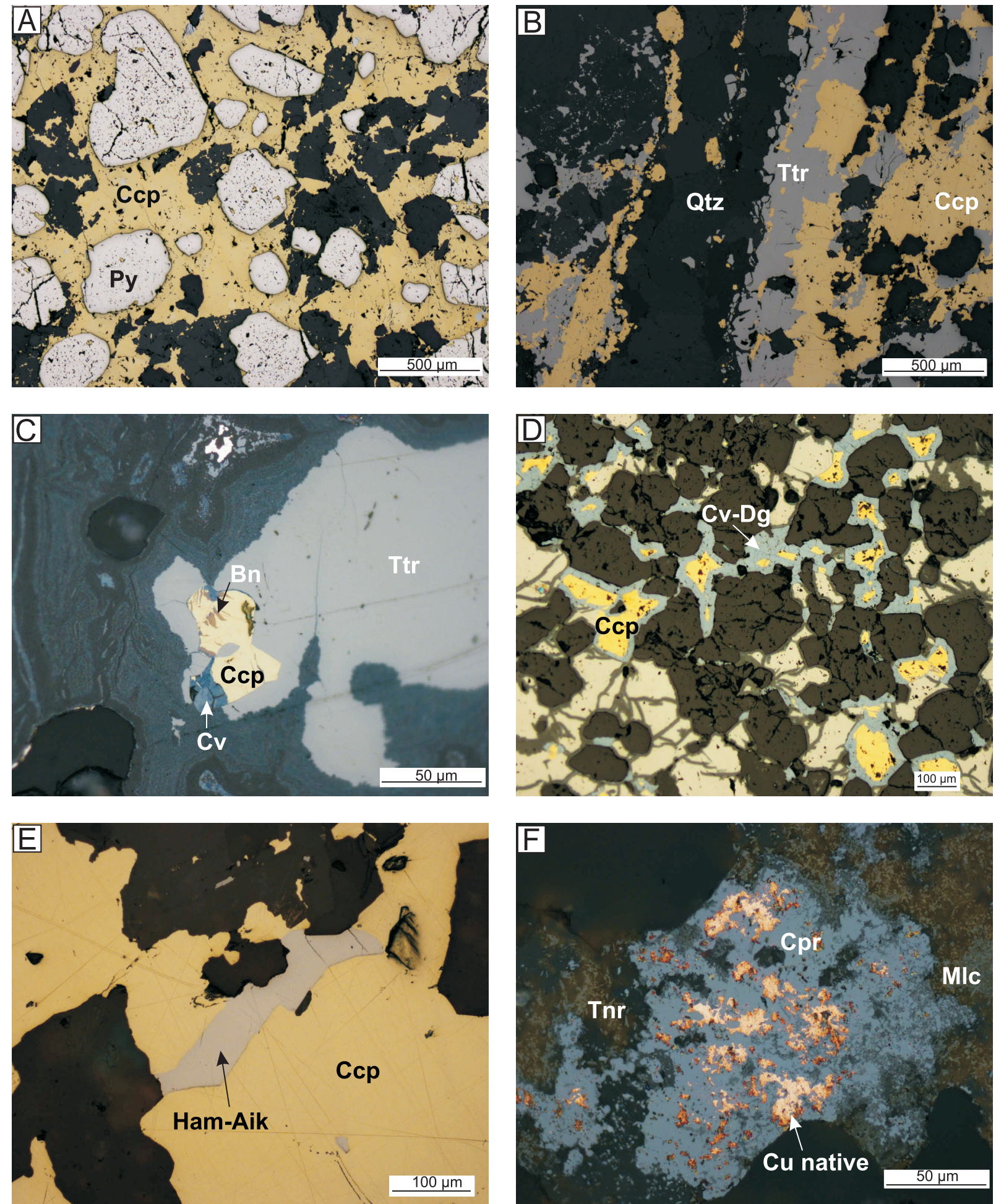

Fig. 4. Representative photomicrographs of ore samples

A - intergrowth of subhedral pyrite crystals with chalcopyrite; B - intergrowth of tetrahedrite with chalcopyrite along a quartz vein; C - bornite with chalcopyrite, chalcopyrite partly altered to covellite; D - intergrowth of chalcopyrite with tetrahedrite rimmed with covellite-digenite; $\mathbf{E}$ - intergrowth of bismuth sulphosalt minerals, hammarite-aikinite with chalcopyrite; $\mathbf{F}$ - relics of metallic copper in cuprite, tenorite and malachite; Py - pyrite, Ccp - chalcopyrite, Qtz - quartz, Bn - bornite, Cv - covellite, Ttr - tetrahedrite, $\mathrm{Dg}$ - digenite, Ham - hammarite, Aik - aikinite, $\mathrm{Cu}$ - native copper, $\mathrm{Cpr}$ - cuprite, $\mathrm{Tnr}$ - tenorite, Mlc - malachite 

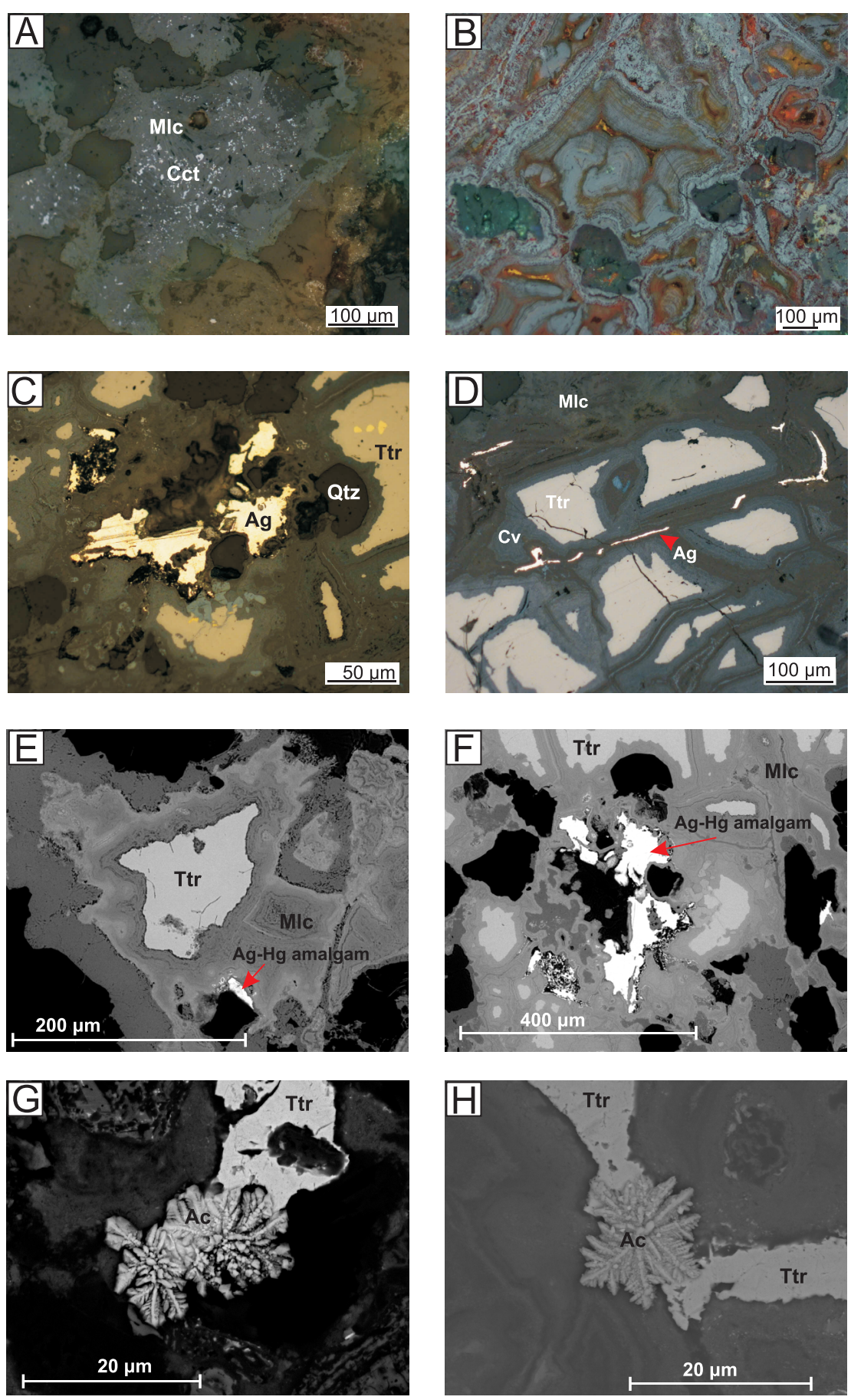

Fig. 5. Representative photomicrographs and BSE images of ore samples

A - intergrowth of chalcocite crystals in malachite; B - box-work texture of Fe-oxides and Fe-hydroxides, as an effect of oxidation; $\mathbf{C}$ - silver overgrowing a quartz grain associated with tetrahedrite; $\mathbf{D}$ - replacement textures of an oxide association composed of malachite and covellite after tetrahedrite rimmed by silver amalgam; $\mathbf{E}$ - altered tetrahedrite with malachite, pale white are $\mathrm{Ag}-\mathrm{Hg}$ amalgams (BSE image); $\mathbf{F}$ - position of the $\mathrm{Ag}-\mathrm{Hg}$ amalgams in relation to tetrahedrite and malachite (BSE image); G, H - acanthite star on the edge of tetrahedrite (BSE image); Cct - chalcocite, Mlc - malachite, $\mathrm{Ag}$ - native silver, Qtz - quartz, Ttr - tetrahedrite, C v - covellite, Ac - acanthite 
teration stage (Fig. 5G, H). The parameters of electron microprobe beam were too high and it decomposed during WDS measurements. This mineral was identified based on optical properties in reflected light and was also confirmed by EDS spectra.

\section{GEOCHEMISTRY OF SELECTED ORE MINERALS}

\section{SILVER MINERALS}

Representative microprobe analytical results of silver amalgams are given in Appendix $1^{*}$. The following elements have been measured: $\mathrm{Ag}, \mathrm{Hg}, \mathrm{Cu}$ and $\mathrm{Fe}$, additionally $\mathrm{Au}, \mathrm{Sb}, \mathrm{Bi}$ and As were sought but not detected. The EPMA analytical data of the silver grains showed that the content of $\mathrm{Ag}$ ranges from 73.40 to 98.55 wt.\% and $\mathrm{Hg}$ ranges from 2.15 to 26.69 wt.\%. Only one measurement point showed chemical composition very similar to eugenite $\left(\mathrm{Ag}_{9} \mathrm{Hg}_{2}-\mathrm{Ag}_{11} \mathrm{Hg}_{2}\right)$ (Kucha, 1986). The compositional ranges of silver amalgams are illustrated in the $\mathrm{Ag}-\mathrm{Hg}$ binary diagram (Fig. 6). Electron microprobe mapping of trace-element distribution in silver grains showed a zonal texture, with the central part containing an elevated amount of $\mathrm{Hg}$, correlating with a slightly lower Ag content (Fig. 7). The zonation is also visible in the BSE image (Fig. 7A).

\section{TETRAHEDRITE}

Representative microprobe analytical results of tetrahedrite are given in Appendix 2, including the minimum and maximum contents of major elements, such as S, Sb, Ag, Cu, Fe, Zn, As, $\mathrm{Hg}, \mathrm{Bi}, \mathrm{Co}$ and $\mathrm{Ni}$. Pb, Te and Se were measured but not detected. Tetrahedrites are rather uniform in composition, are not zoned (Fig. 5E), and no exsolution or micro-inclusions of other sulphides have been found within them. The percentage of copper in tetrahedrite ranges from 39.40 to $40.17 \mathrm{wt}$ \% $\%$ while the Ag content is up to $0.32 \mathrm{wt} . \%$. The mercury content is not high; however, it is always above detection limits and the level of 0.08 to $0.18 \mathrm{wt}$ \%. The zinc content is ranging up to $1.90 \mathrm{wt} . \%$ while the Fe content is always higher, up to 4.53 wt.\%, which indicates that the hydrothermal fluid was iron sufficient. The sulphur content is between 24.65 and 25.25 wt. $\%$.

\section{Bi-SULPHOSALT MINERALS}

The bismuthinite-aikinite isomorphic series comprises a combination of krupkaite $\left(\mathrm{CuPbBi}_{3} \mathrm{~S}_{6}\right)$ with two end-members of bismuthinite $\left(\mathrm{Bi}_{4} \mathrm{~S}_{6}\right)$ and aikinite $\left(\mathrm{Cu}_{2} \mathrm{~Pb}_{2} \mathrm{Bi}_{2} \mathrm{~S}_{6}\right)$ (Makovicky and Makovicky, 1978; Topa et al., 2002; Petricek and Makovicky, 2006). The chemical formula of series members is based on the substitution $\mathrm{Cu}+\mathrm{Pb} \leftrightarrow \square+\mathrm{Bi}$ (where $\square$ is a vacant tetrahedral position), while the empirical formula is $\mathrm{Cu}_{x} \mathrm{~Pb}_{y} \mathrm{Bi}_{8-0.5(x+y)} \mathrm{S}_{12}$ based on $(\mathrm{Cu}+\mathrm{Pb}) / 2+\mathrm{Bi}=8$ atoms per formula unit, where $\mathrm{x}$ is approximately equal to y (Makovicky and Maskovicky, 1978; Pring, 1989; Putz et al., 2003).

Bi-sulphosalt minerals in investigated samples have been observed mainly within chalcopyrite and sometimes also in pyrite (Figs. 4E and 8A, B). The microprobe results are shown in Appendix 3 and are plotted in the $\mathrm{Bi}-\mathrm{Cu}-\mathrm{Pb}$ ternary diagram (Fig. 9) of bismuthinite derivatives to compare with the Beiya skarn gold deposit (Zhou et al., 2016) and the Yoan gold deposit (Zhou et al., 2018) in Yunnan, China.

Bismuth sulphosalts from the Kyaukse Sabe Taung copper deposit contain $43.04 \% \mathrm{Bi}, 10.48 \% \mathrm{Cu}$ and $29.52 \% \mathrm{~Pb}$ with $\mathrm{n}_{\text {aikinite }}=87.21$ (Friedrichite), $51.92 \% \mathrm{Bi}, 23.47 \% \mathrm{~Pb}$ and $8.15 \%$ Cu with $\mathrm{n}_{\text {aikinite }}=66.45$ (hammarite) and $50.74 \% \mathrm{Bi}, 24.80 \% \mathrm{~Pb}$ and $8.36 \% \mathrm{Cu}$ with $\mathrm{n}_{\text {aikinite }}=68.86$ (hammarite), which are very similar to the compositions of Bi-sulphosalt minerals from Ferbertal, Austria (Topa et al., 2002). The calculated $n_{\text {aikinite }}$ values (Appendix 4) range from 66.45 to 88.61 and on the ternary plot (Fig. 9) show a continuous series between hammarite and friedrichite with grains of intermediate compositions between hammarite - friedrichite and fridrichite-aikinite. The $\mathrm{Cu}: \mathrm{Pb}$ values are between 1.03 and 1.16 .

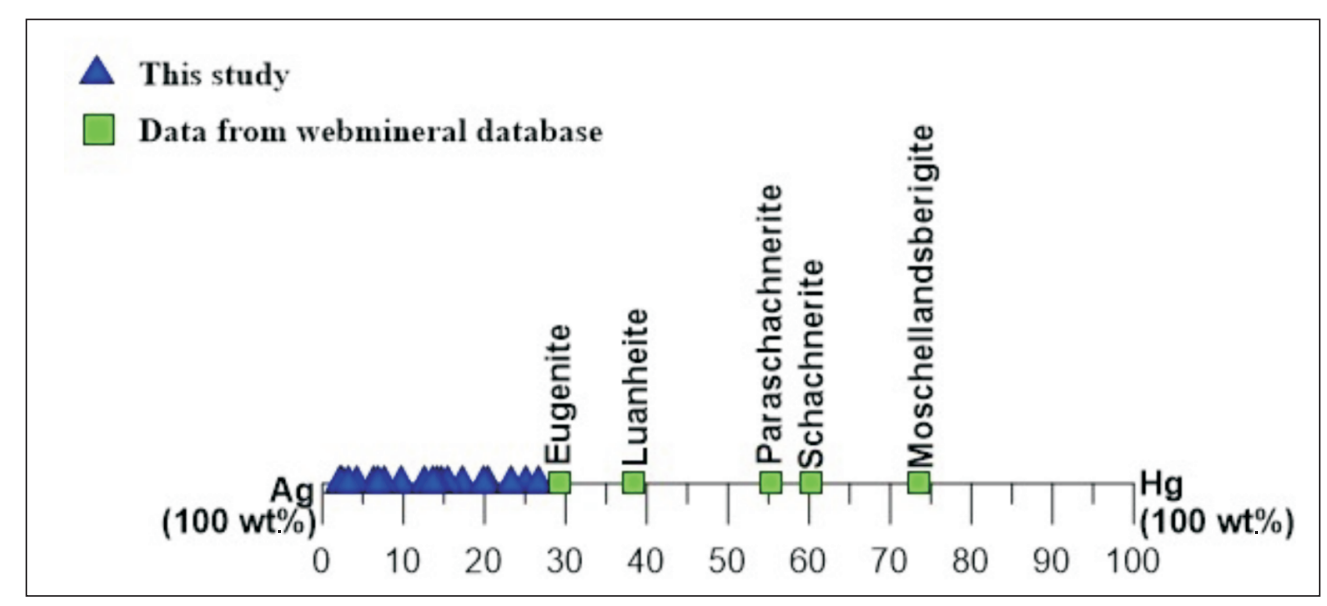

Fig. 6. Composition of amalgams in the Ag-Hg binary diagram (based on analytical data - wt.\%; after Piestrzyński and Tylka, 1992)

\footnotetext{
* Supplementary data associated with this article can be found, in the online version, at doi: $10.7306 / \mathrm{gq} .1514$
} 

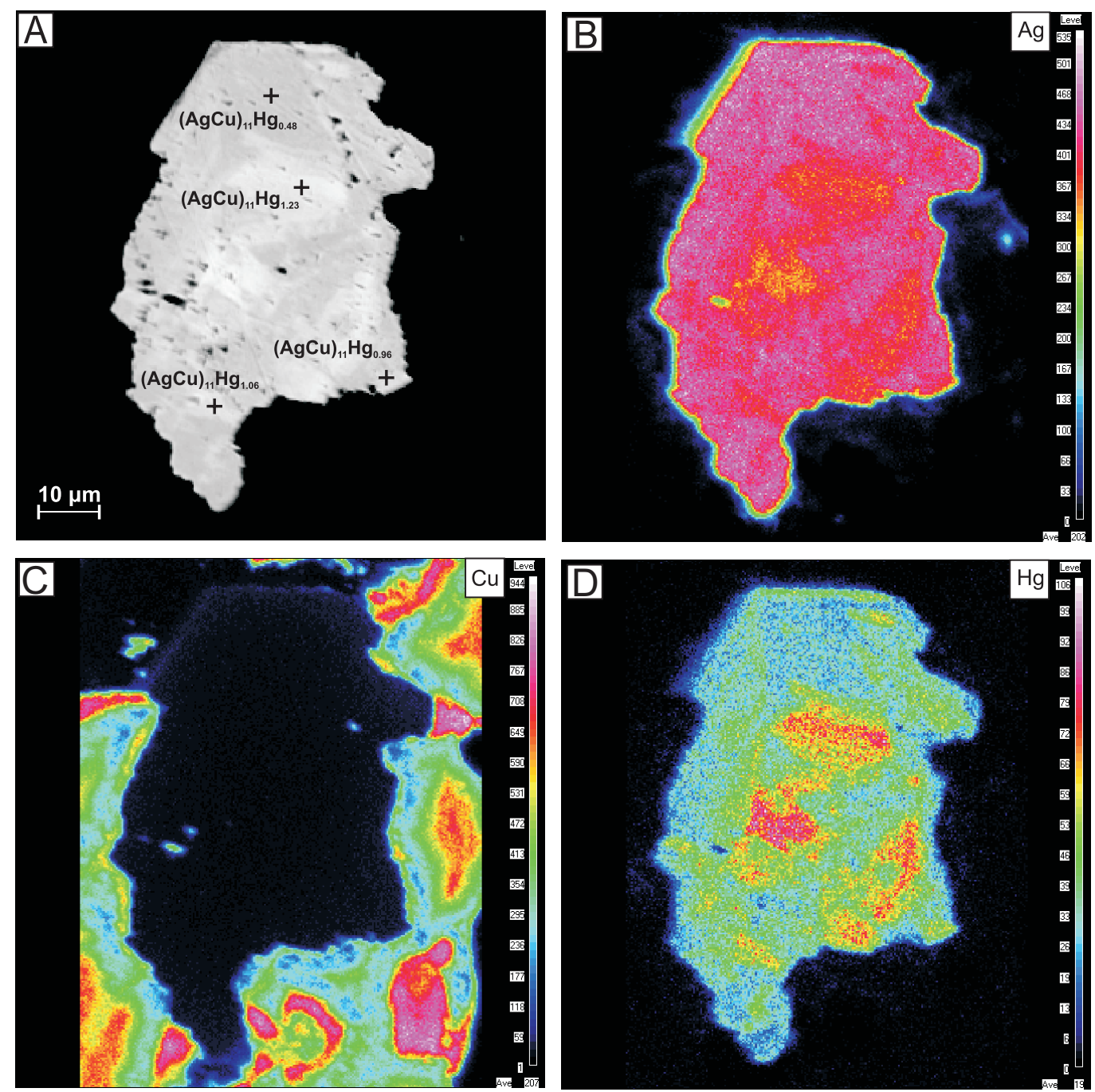

Fig. 7. Electron microprobe mapping of trace-element distribution in a single euhedral crystal of silver amalgams from the Kyaukse Sabe Taung copper deposit

A - BSE image, B - silver distribution, C - copper distribution, D - mercury distribution
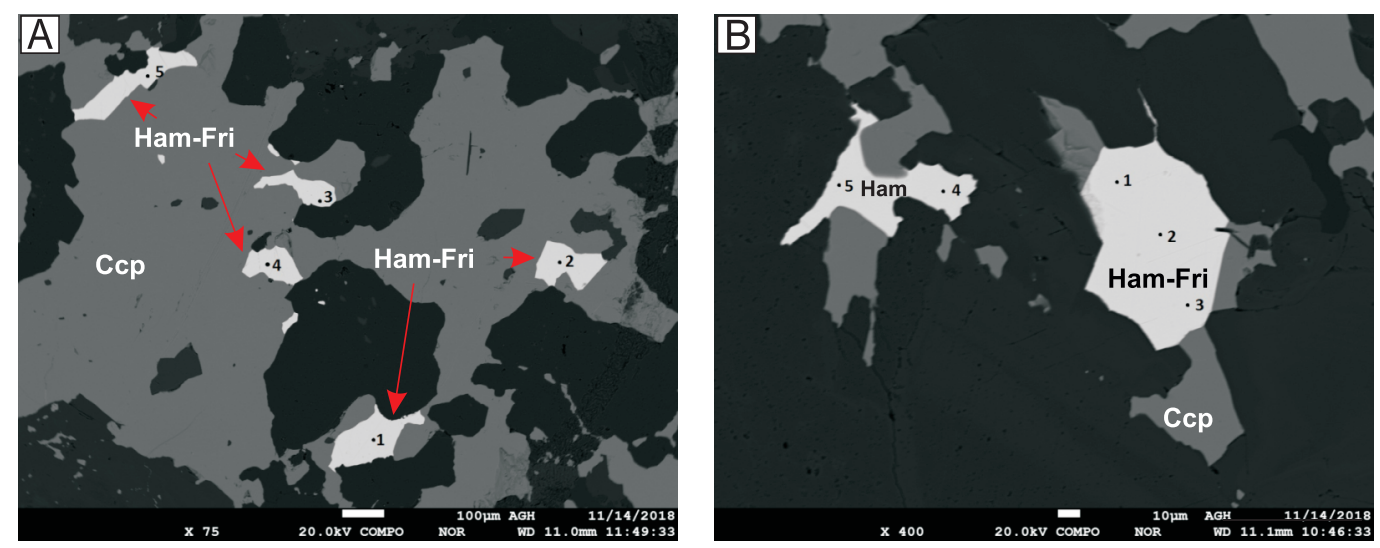

Fig. 8A, B - BSE images of Bi-sulphosalts and chalcopyrite intergrowths

Ham - hammarite, Ham-Fri - hammarite-friedrichite, Ham-Aik - hammarite-aikinite, Ccp - chalcopyrite 


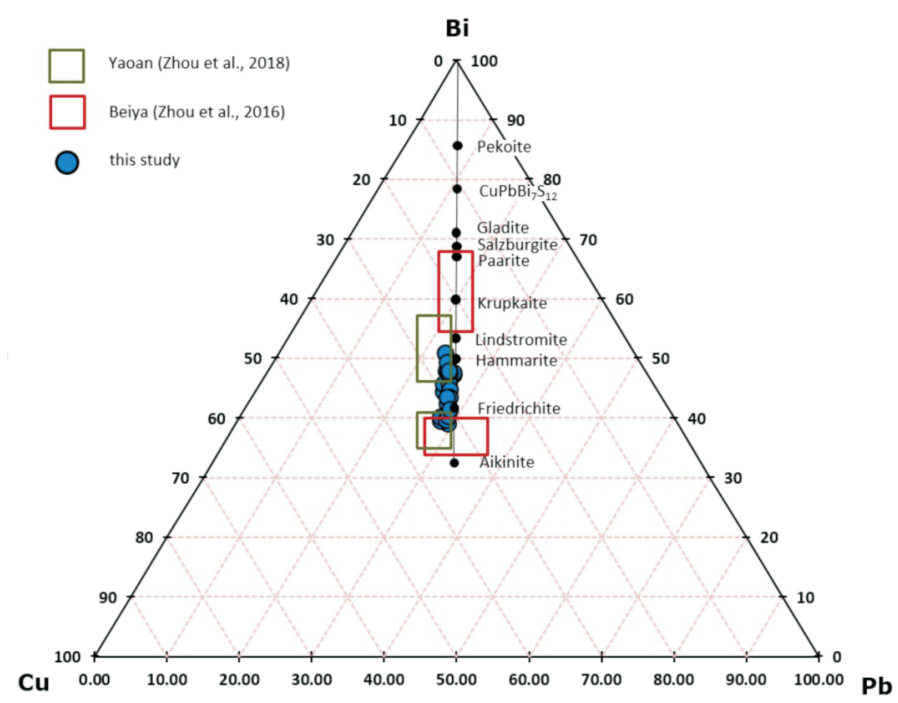

Fig. 9. $\mathrm{Cu}-\mathrm{Pb}-\mathrm{Bi}$ plot showing the comparison of bismuthinite derivatives from the Kyaukse Sabe Taung copper deposit, Myanmar, with the Yaoan and Beiya skarn gold deposit in SW China (Zhou et al., 2016, 2018)

\section{CARBONATES}

Carbonates are very common in the deposit and were present in almost all investigated samples. In this deposit, two groups of carbonates can be distinguished: the first consists of host carbonates (calcite) metamorphosed during regional metamorphism under the conditions of greenschist facies, while the second group, represented by ankerite and dolomite, is hydrothermal in origin and related to mineralization. Ankerite-dolomite crystals are characterized by zonation with different Fe contents (Fig. 10), as shown by Energy-dispersive X-ray spectroscopy (EDS) (Table 1). Ankerite has a higher Fe content (up to 11.19 wt.\%) relative to $\mathrm{Mg}$ (7.67 wt.\%), while opposite is true for ferroan dolomite (Fe content $5.21 \mathrm{wt} . \%$ and $\mathrm{Mg}$ content 11.42 wt. \%).

\section{SULPHUR ISOTOPES}

Among the principal reservoirs of sulphur, $\delta^{34} S$ values of magmatic sulphur tend to cluster around $0 \%$ and magmatic sulphur could be precipitated directly from a mantle-derived magma or could be remobilized from magmatic rocks and precipitated by a subsequent magmatic event (Ohmoto and Rye, 1979). Secondly, sulphur from seawater sulphate usually shows higher

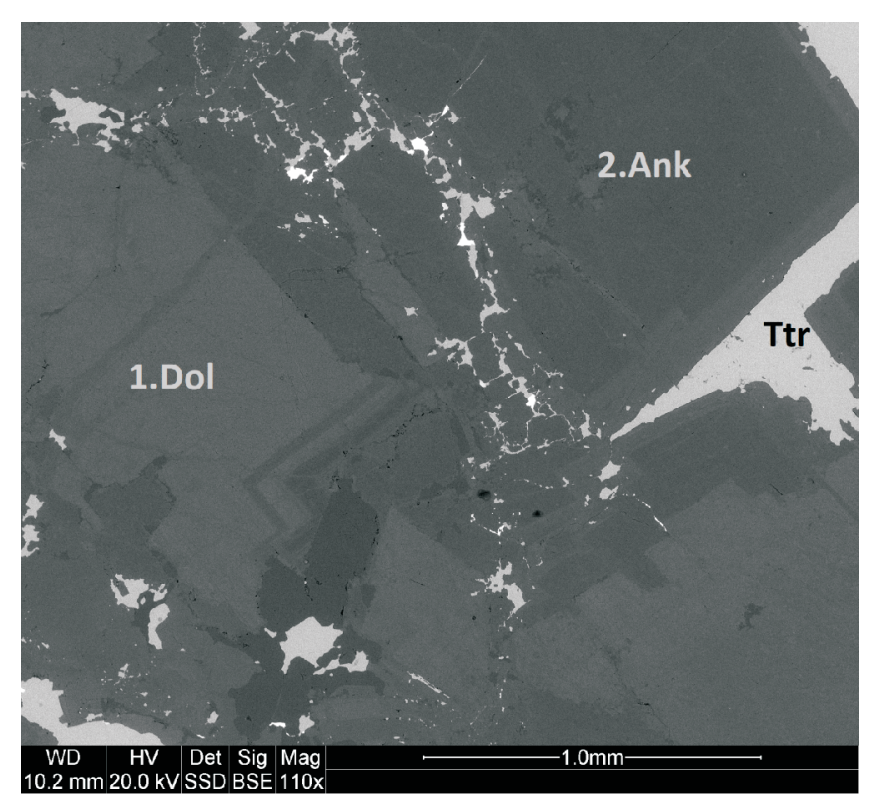

Fig. 10. BSE image of zoned ferroan dolomite (Dol) and ankerite (Ank) intergrown with tetrahedrite (Ttr)

SEM/EDS chemical analysis of ankerite-dolomite

\begin{tabular}{|c|c|c|c|c|c|c|c|c|}
\hline Analysis & $\mathrm{C} \mathrm{K} \alpha$ & $\mathrm{O} \mathrm{K} \alpha$ & $\mathrm{Mg} \mathrm{K} \alpha$ & $\mathrm{Ca} \mathrm{K}$ & $\mathrm{Mn} \mathrm{K} \alpha$ & $\mathrm{Fe} \mathrm{K} \alpha$ & $\mathrm{Co} \mathrm{K} \alpha$ & $\mathrm{Total}$ \\
\hline \multirow{3}{*}{ Spot 1 } & 17.48 & 43.54 & 7.67 & 19.1 & 0.71 & 11.19 & 0.31 & 100 \\
\cline { 2 - 10 } & 28.05 & 52.47 & 6.08 & 9.19 & 0.25 & 3.86 & 0.10 & 100 \\
\hline \multirow{2}{*}{ Spot 2 } & 18.68 & 44.22 & 11.42 & 19.79 & 0.4 & 5.21 & 0.28 & 100 \\
\cline { 2 - 10 } & 28.87 & 51.29 & 8.72 & 9.16 & 0.14 & 1.73 & 0.09 & 100 \\
\hline
\end{tabular}


$\delta^{34} \mathrm{~S}$, of $\sim 21.0 \%$ for dissolved sulphate in modern oceans, and these heavy $\delta^{34} S$ values are considered to represent a major contribution of seawater-derived sulphate.

Sulphur isotope composition of chalcopyrite and tetrahedrite from the Kyaukse Sabe Taung copper deposit was measured and results are shown in Table 2. The $\delta^{34} S$ values of chalcopyrite range from +5.7 to $+10.7 \%$ and those of tetrahedrite are significantly lower, ranging from +1.6 to $+1.7 \%$. Since sulphur isotopic compositions were obtained for only six samples, it is difficult to draw definitive conclusions regarding the source of sulphur. However, such differences suggest variations in the physical-chemical conditions of ore forming fluids or the source of sulphur may not be a homogeneous reservoir. A deep-seated magmatic igneous source for sulphur $\left(\delta^{34} S=0 \pm 2 \%\right.$; Ohmoto and Rye, 1979) can explain the S isotope values of tetrahedrite, and is justified on geological grounds, taking into account a diorite intrusion outcropping in this area. Higher values for chalcopyrite could suggest some contribution of the sulphur derived from modified seawater, or it could be sourced from reservoirs containing both magmatic and reduced seawater sulphate, and/or that the mixing occurred between these two end-member reservoirs (Ohmoto and Rye, 1979).

\section{DISCUSSION}

The evidence from the field investigations revealed that the copper sulphide veins are injected or distributed along the fissures in the Middle Ordovician limestone of the Wunbye Formation and clearly later than the host rocks (Fig. 3C). Microscopic studies confirmed a pervasive alteration of country rocks, mainly carbonates, and the mineralization seems to be linked to intense silicification, chloritization, kaolinization, carbonatization and hematitization. Sulphides represented by pyrite, tetrahedrite, and chalcopyrite crystallized during the first stage and are related to quartz veins (Fig. 4B). In this association, pyrite is older and followed by tetrahedrite and chalcopyrite (Fig. 4A-C). Bornite is probably younger and formed during solid solution segregation within the chalcopyrite (Fig. 4C). Simple copper sulphides, such as covellite, were developed as a rim surrounding tetrahedrite grains (Fig. 4D). Simultaneously, Bi-sulphosalt mineralization was developed (compare Fig. 4E and Table 3). The copper minerals were precipitated probably at a moderate temperature range from hydrothermal solutions related either to the nearby diorite intrusion or to the regional metamorphism stage of greenschist facies (Aung Myo Thu, 2014).

Silver minerals, represented by acanthite and silver amalgams, are observed in close association with tetrahedrite.
Supergene alteration of $\mathrm{Ag}$ - and $\mathrm{Hg}$-bearing tetrahedrite (Appendix 2) released these metals and led to the formation of an assemblage consisting of acanthite, $\mathrm{Ag}-\mathrm{Hg}$ amalgams, covellite, chalcocite, malachite, tenorite, native copper and Fe-hydroxides (Fig. 5A-H). Precipitation of new mineral phases took place on the redox barrier (possibly water table level) and the silver association is located within the lowermost part of the supergene zone in the deposit. Tracking the redox barrier position in the deposit can help to identify parts of the orebody with silver enrichment. Silver amalgams are the major Ag-bearing phase in the deposit and could be a potential by-product, increasing deposit's economic value.

The position of carbonates, especially those showing zoning (Fig. 10), suggests crystallization in open space. The ankerite-dolomite series was probably crystallized at the end of sulphide hypogenic stage and at the beginning of tetrahedrite alteration (Fig. 10). However, in the zone of oxidation, which depends on the water level, Fe-hydroxides were also precipitated.

\section{CONCLUSIONS}

Based on the field study, textural investigations, and mineralogical and chemical analyses, the following conclusions can be drawn:

- The copper and silver mineralization at the Kyaukse Sabe Taung deposit is located within quartz-calcite veins and veinlets in silicified limestone.

- Chalcopyrite, tetrahedrite and bornite form hypogene ore, while chalcocite, covellite, malachite and Fe-hydroxides form the bulk of supergene association.

- We report the presence of several $\mathrm{Bi}-\mathrm{Pb}-\mathrm{Cu}$ phases, which were not previously described in this area.

- Ag-Hg amalgams have been identified as the main carriers of silver in the deposit, occurring as free grains and as a coating of quartz grain, and were formed during the late stage of supergene alteration of $\mathrm{Ag}$ - and $\mathrm{Hg}$-bearing tetrahedrite.

- The study results (Bi-Pb-Cu assemblages, silver amalgams, intense alteration, structural control, sulphur isotopes) indicate that the classification of the Kyaukse Sabe Taung $\mathrm{Cu}$ deposit as a modified MVT//rish-type deposit is doubtful. The model of structurally controlled orogenic base metal-gold mineralization is more consistent with the presence of Bi-sulphosalts and ankerite. These features, found in many hydrothermal and/or orogenic gold deposits, indicate that the study area could be also prospective for gold mineralization. Detailed studies of fluid inclusions and stable isotopes $(\mathrm{S}, \mathrm{C}, \mathrm{O}, \mathrm{H})$ are still required to understand the depositional conditions and origin of this deposit, but it is

$\delta^{34} \mathrm{~S}$ values of sulfides from the Kyaukse Sabe Taung copper deposit

\begin{tabular}{|l|c|l|l|c|}
\hline Sample & Formation & Ore Type & Mineral & $\delta^{34} \mathrm{~S}[\%]$ \\
\hline $\mathrm{Sb}-001$ & Wunbye & Vein type sulphide ore & Chalcopyrite & 10.7 \\
$\mathrm{Sb}-002$ & Wunbye & Vein type sulphide ore & Chalcopyrite & 6.9 \\
$\mathrm{Sb}-004$ & Wunbye & Vein type sulphide ore & Tetrahedrite & 1.7 \\
$\mathrm{Sb}-004.1$ & Wunbye & Vein type sulphide ore & Tetrahedrite & 1.6 \\
$\mathrm{Sb}-009$ & Wunbye & Vein type sulphide ore & Chalcopyrite & 5.7 \\
$\mathrm{Sb}-010$ & Wunbye & Vein type sulphide ore & Chalcopyrite & 5.7 \\
\hline
\end{tabular}


Sequences of mineral paragenesis at the Kyaukse Sabe Taung copper deposit

\begin{tabular}{|c|c|c|}
\hline ALTERATION / MINERALS & $\begin{array}{l}\text { HYPOGENE } \\
\text { MINERALS }\end{array}$ & SUPERGENE MINERALS \\
\hline \multicolumn{3}{|l|}{ Silicification } \\
\hline \multicolumn{3}{|l|}{ Kaolinization } \\
\hline \multicolumn{3}{|l|}{ Carbonization } \\
\hline \multicolumn{3}{|l|}{ Hematization } \\
\hline \multicolumn{3}{|l|}{ Chloritization } \\
\hline \multicolumn{3}{|l|}{ Quartz } \\
\hline \multicolumn{3}{|l|}{ Pyrite } \\
\hline Chalcopyrite & E & -------- \\
\hline Tetrahedrite & & --------- \\
\hline \multicolumn{3}{|l|}{ Bornite } \\
\hline \multicolumn{3}{|l|}{ Chalcocite } \\
\hline \multicolumn{3}{|l|}{ Covellite-digenite } \\
\hline \multicolumn{3}{|l|}{ Hammarite-Aikinite series } \\
\hline \multicolumn{3}{|l|}{ Ankerite } \\
\hline \multicolumn{3}{|l|}{ Dolomite } \\
\hline \multicolumn{3}{|l|}{ Malachite } \\
\hline \multicolumn{3}{|l|}{ Azurite } \\
\hline \multicolumn{3}{|l|}{ Silver amalgams } \\
\hline Acanthite & & 工 \\
\hline \multicolumn{3}{|l|}{ Calcite } \\
\hline \multicolumn{3}{|l|}{ Cu native } \\
\hline \multicolumn{3}{|l|}{ Cuprite } \\
\hline Tenorite & & - \\
\hline Fe-hydroxides & & \\
\hline
\end{tabular}

likely related to supergene alteration of the mineralized vein formed by fluids related to magmatic intrusion.

Acknowledgements. The authors are grateful to Professor J. Pieczonka for her advices and suggestions. The authors also want to thank UNESCO AGH Chair for supporting this research and AGH grant No. 11.11.140.161. Special thanks are due to Professor K. Zaw and anonymous reviewers for their insightful comments and advice, which substantially improved the manuscript. We would like to express our most sincere gratitude to $G$. Kozub-Budzyń for her professional and excellent work with the SEM-EDS and EPMA analysis during this project.

\section{REFERENCES}

Aung Myo Thu, 2014. Metamorphic Petrology of the Seywa-Kyungyi Area, Ywangan Township, Southern Shan State, Myanmar. M.Sc. thesis, Mandalay University.

Barley, M.E., Pickard, A.L., Zaw, K., Rak, P., Doyle, M.G., 2003. Jurassic to Miocene magmatism and metamorphism in the Mogok metamorphic belt and the India Eurasia collision in Myanmar. Tectonics, 22: 1019.

Bender, F., 1983. Geology of Burma. Gebrüder Borntraeger, Berlin.

Bertrand, G., Rangin, C., 2003. Tectonics of the western margin of the Shan plateau (central Myanmar): implication for the India-Indochina oblique convergence since the Oligocene. Journal of Asian Earth Sciences, 21: 1139-1157.

DGSE, 2013. The Database on Mineral Occurrences of Myanmar. Unpublished Report, Department of Geological Survey and Mineral Exploration.

Dew, R., Morley, C.K., Myint, T.A., Collins, A., 2019. Age and provenance of the Chaung Magyi Group, Yeywa Dome, Myanmar, based on U-Pb dating of detrital zircons. Journal of Asian Earth Sciences, 184: 103967.

Khin Zaw, Ye Myint Swe, Tin Aung Myint, Knight, J., 2017. Chapter 26 Copper deposits of Myanmar. In: Myanmar: Geology, Re- sources and Tectonics (eds. A.J. Barber, Khin Zaw, M.J. Crow): 573-588. Geological Society, London.

Kucha, $\mathrm{H}$., 1986. Eugenite, $\mathrm{Ag}_{11} \mathrm{Hg}_{2}-\mathrm{a}$ new mineral from Zechstein copper deposits in Poland. Mineralogia Polonica, 17: 3-12.

Kyu Kyu Maw, 2014. Mineral resources of the Sabetaung-Chaungzon-Pyittawye Area, Kyaukse Township, Mandalay Region. University Research Journal, 6: 126-141.

La Touche, T.H.D., 1913. Geology of the Northern Shan States. Memoir of the Geological Survey of India, 39: 1-379.

Maung Thein, 1973. A preliminary synthesis of the geological evolution of Burma with reference to the tectonic development of Southeast Asia. Geological Society of Malaysia, Bulletin, 6: 87-116.

Makovicky, E., Makovicky, M., 1978. Representation of compositions in the bismuthinite-alkinite series. The Canadian Mineralogist, 16: 405-409.

Mitchell, A.H.G., Htay, M.T., Htun, K.M., Win, M.N., Oo, T., Hlaing, T., 2007. Rock relationships in the Mogok metamorphic belt, Tatkon to Mandalay, central Myanmar. Journal of Asian Earth Sciences, 29: 891-910. 
Mitchell, A.H.G., 2018. Geological Belts, Plate Boundaries and Mineral Deposits in Myanmar. Elsevier, Amsterdam.

Myint Lwin Thein, 1973. The Lower Paleozoic stratigraphy of western part of the Southern Shan State, Burma. Geological Society of Malaysia Bulletin, 6: 143-163.

Ohmoto, H., Rye, R.O., 1979. Isotopes of sulfur and carbon. In: Geochemistry of Hydrothermal Ore Deposits (ed. H.L. Barnes): 509-567. John Wiley and Sons, New York.

Petřiček, V., Makovicky, E., 2006. Interpretation of selected structures of the bismuthinite-aikinite series as commensurately modulated structures. The Canadian Mineralogist, 44: 189-206.

Piestrzyński, A., Tylka, W., 1992. Silver amalgams from Sieroszowice copper mine, Lubin-Sieroszowice district, SW Poland. Mineralogia Polonica, 23: 17-25.

Pring, A., 1989. Structural disorder in aikinite and krupkaite. American Mineralogist, 74: 250-255.

Putz, H., Paar, W.H., Topa, D., Horner, J., Lüders, V., 2003. Structurally controlled gold and sulfosalt mineralization: the Alten- berg example, Salzburg Province, Austria. Mineralogy and Petrology, 78: 111-138.

Topa, D., Makovicky, E., Paar, W.H., 2002. Composition ranges and exsolution pairs for the members of the bismuthinite-aikinite series from Felbertal, Austria. The Canadian Mineralogist, 40: 849-869.

Tin Aung Myint, San San Win, Than Than Nu, 2014. Characterization of the copper and base metals occurrence in the Pein Ye Taung-Le Lon Taung area, Mandalay Region. Mandalay University Research Journal, 5: 208-217.

Zhou, H., Sun, X., Fu, Y., Lin, H., Jiang, L., 2016. Mineralogy and mineral chemistry of Bi-minerals: constraints on ore genesis of the Beiya giant porphyry-skarn gold deposit, southwestern China. Ore Geology Reviews, 79: 408-424.

Zhou, H., Sun, X., Wu, Z., Yang, T., Li, D., Ren, Y., Liu, Q., Zhu, K., $\mathrm{Yu}, \mathbf{H}$., 2018. Mineralogy of Bi-sulfosalts and tellurides from the Yaoan gold deposit, southwest China: metallogenic implications. Ore Geology Reviews, 98: 126-140. 